\title{
Três Variantes do Personalismo na Política da América Hispânica: o Caudilhismo, o Bolivarianismo e o Populismo como Expressões de Afirmação Regional
}

\author{
Francisco Mata Machado Tavares ${ }^{(*)}$
}

\begin{abstract}
Resumo: Este artigo discute, sob prisma teorético-político, três variantes da legitimação carismática do poder identificadas na América Hispânica em diferentes momentos históricos. O objetivo é identificar os atributos comuns e as distinções entre o caudilhismo, o bolivarianismo e o populismo. O argumento que se pretende justificar é o de que o personalismo político se relaciona significativamente com a afirmação da autonomia subcontinental e, portanto, com a negação da legitimação legal-racional consubstanciada no constitucionalismo de origem europeia. Haveria, assim, uma paradoxal relação entre a autonomia dos cidadãos pressuposta no ideário constitucionalista e a afirmação da autonomia local intrínseca às expressões de personalismo.
\end{abstract}

Abstract: This article discusses, from a political-theoretical approach, three variants of the charismatic legitimation of power that are identified, along different historical epochs, in Hispanic America. The goal is to identify the common features and the differences between caudilism, bolivarianism and populism. The argument I intend to justify is that the political personalism in this subcontinent is closely related to the affirmation of its regional autonomy, and, thus, to the denial of the legalist-rationalist legitimation consubstantiated in the European constitutionalism. There would be, thus, a paradoxical relation between the citizenry autonomy pressupposed in the constitutional ideal, and the local autonomy, which is intrinsic to the expressions of personalism in Hispanic America.

(*) Doutorando em Ciência Política na Universidade Federal de Minas Gerais — UFMG. Professor Assistente da Faculdade de Ciências Sociais da Universidade Federal de Goiás - UFG. E-mail: < francktavares@hotmail.com>. Recebido em 5.1.2011 e aceito em 27.6.2011. 


\section{INTRODUÇÃO}

As idiossincrasias da geografia, da história, da cultura e, de um modo particular, da política na América Hispânica, se constituem como recorrente desafio teórico e metodológico às formulações que ambicionam enquadrar tão peculiar subcontinente em conceitos e categorias de gênese estrangeira, frequentemente forjados em contextos, como o europeu ou o estadunidense, significativamente distintos em relação ao canto do globo um dia definido por José Martí como "Nossa América". Em especial, no que tange aos estudos sociais, decorre do caráter peculiar da América Latina, em geral e, especialmente, da América Hispânica, uma comum limitação ou mesmo precariedade do instrumental analítico hegemônico para fins de caracterização dos processos, instituições, comportamentos, valores e costumes observáveis na região.

Assim, não raramente identificam-se aparentes ambiguidades ou contradições na realidade hispano-americana, como meio de se explicar sua não subsunção a clivagens cunhadas para a compreensão de cenários europeus ou norte-americanos, tais como democracia $\mathrm{x}$ ditadura, liberalismo x conservadorismo, modernização x atraso, ou civilização x barbárie. Em suma, o excessivo apontamento de tensões ou quadros ambíguos não se desdobra, necessariamente, de uma instabilidade ou desarmonia social na América Latina, mas, de modo oposto, pode apenas indicar os limites metodológicos de uma ciência social que pretende compreender o mundo a partir de ferramentas lógicas e conceituais etnocêntricas.

Estabelecidas as ressalvas acima, ainda é possível, em grau de coerência com o ânimo universalizante da ciência moderna, constatar-se que o estabelecimento de diálogos entre a linguagem da ciência social europeia ou estadunidense e a realidade da América Hispânica não implica, necessariamente, uma mecânica caracterização do subcontinente segundo parâmetros que lhe são estranhos. Tal se dá por duas razões: a) primeiramente, porque é inegável que a América Latina, em sua constituição social ao longo de séculos, em muito fora influenciada pela cultura e por valores europeus, de modo que o assim chamado Ocidente é uma de suas determinantes raízes e; b) ademais, é possível reconhecer-se que, no contexto da epistemologia ocidental, há uma clara abertura — desde que se irrompa para além do marco positivista - para a ressignificação de categorias e instituições a partir da interação com outras culturas, conforme esclarece Jürgen Habermas:

A permanente suspeita desconstrutivista das limitações eurocêntricas provoca a questão inversa: por que o modelo hermenêutico de entendimento, adquirido nas conversas cotidianas e desenvolvido metodologicamente desde Humboldt a partir da prática de interpretação de textos deveria, além das fronteiras da própria cultura, da própria forma de vida, subitamente fracassar? [ .... Na dinâmica dessa tomada de perspectiva recíproca reside a cooperação que leva à produção de um horizonte interpretativo comum, no qual ambos os lados podem chegar a uma interpretação, que não resulta de uma apropriação etnocêntrica ou de uma conversão, mas que é partilhada intersubjetivamente. (HABERMAS, 2006, p. 23-24.)

As considerações metodológicas acima tecidas se propõem a contextualizar o propósito deste breve trabalho, concernente em compreender um fenômeno político recorrente na história da América Latina, a ser definido segundo uma tipificação de origem weberiana, 
aqui apropriada e adaptada a partir das especificidades da América Hispânica. Trata-se do personalismo como fator de coesão e de identidade político-estatal, assim entendido como espécie do tipo ideal legitimação do poder segundo o carisma do governante $^{(1)}$.

Esse caso específico de liderança carismática, o personalismo, é o objeto deste sucinto estudo. Em grau de paralelismo — e, sob certa medida, de rivalização — com o constitucionalismo (em outros termos, com a legitimação do domínio estatal segundo o respeito à legalidade $\left.{ }^{(2)}\right)$, cuida-se de um dos mais importantes traços da história política da América Latina. Por personalismo, se entende a prevalência, em termos de respeito e de identidade popular, dos atributos do líder político, em detrimento dos limites e atribuições formal-juridicamente prescritos para o respectivo cargo. Nas palavras de John Lynch (1993), para quem o personalismo é o principal legado do poder outrora exercido pelos caudillos, tal ideia assim se define:

[E]l personalismo se traduce en la tendencia popular a guardar mayor lealtad y obediencia al ser que gobierna que al cargo que ostenta. La creencia de que el gobierno y la burocracia deberian aplicar políticas generales de forma imparcial utilizando para ello las instituciones es totalmente ajena a la ideología personalista. (LYNCH, 1993, p. 530.)

Com efeito, desde o caudilhismo, passando-se pelo populismo ascendente a partir dos anos 30 do século XX, até o recente empossamento de governantes como Hugo Chávez, na Venezuela, Rafael Correa, no Equador ou Evo Morales, na Bolívia, nota-se uma inquietante relação entre o carisma e a liderança individual dos governantes hispano-americanos com a conformação de um discurso de legitimação dos respectivos governos, ou mesmo do Estado em cuja gestão se encontram.

$\mathrm{Na}$ esteira das definições acima expostas, a pergunta que se pretende responder neste texto assim se equaciona: como se caracterizam as principais manifestações do personalismo na legitimação do poder político na América hispânica e quais são suas características comuns?

O objetivo a se perseguir é a identificação de traços que aproximem as distintas variações históricas e regionais do personalismo. Para se alcançar tal propósito, serão discutidas as seguintes variações dessa espécie de legitimação carismática da domínio político: i) o fenômeno do caudilhismo e seu legado; ii) as formulações constitucionais e a práxis política de Simon Bolívar; e iii) o populismo como forma urbana e moderna de personalismo ${ }^{(3)}$.

Uma vez perquiridas tais modalidades de personalismo e o modo como se influenciam reciprocamente, identificar-se-á, já na seção reservada às conclusões, por meio de esforço

(1) Nos termos de Weber: "Há a autoridade do dom da graça (carisma) extraordinário e pessoal, a dedicação absolutamente pessoal e a confiança pessoal na revelação, heroísmo ou outras qualidades da liderança individual. É o domínio "carismático" exercido pelo profeta ou - no campo da política - pelo senhor de guerra eleito, pelo governante plebiscitário, o grande demagogo ou o líder do partido político." (WEBER, 1982, p. 99.)

(2) Tal tipo ideal é assim explicado por Weber: "Finalmente, há o domínio em virtude da 'legalidade', em virtude da fé na validade do estatuto legal e da 'competência' funcional, baseada em regras racionalmente criadas." (WEBER, 1982, p. 99.)

(3) Tendo em vista as limitações de espaço e de escopo deste trabalho, não serão abordadas outras variantes do personalismo no subcontinente, tais como os governos militares e os chefes egressos de oligarquias restritas que em seu nome governaram. 
dedutivo de aplicação, para um caso específico, dos tipos identificados, eventuais signos personalistas ocorrentes na liderança política da Venezuela contemporânea, tal como exercida pelo Tenente-coronel Hugo Chávez.

\section{Os Caudilhos em Hispano-América: gênese da legitimação personalista do DOMÍNIO ESTATAL NO SUBCONTINENTE}

O fenômeno do caudilhismo em Hispano-América não encerra um modo único e rigidamente identificável de exercício do poder, mas dá conta de uma variante de personalismo político que, com certas características regulares e origens similares, triunfou entre o início e meados do século XIX, notadamente no contexto imediatamente posterior às lutas independentistas. De Rosas, na Argentina, a Paéz, na Venezuela, é possível identificar-se, em que pese as nuanças decorrentes das especificidades históricas de cada localidade, atributos que permitem a caracterização dos caudillos e do respectivo modo de atuar politicamente, conforme se expõe adiante.

Segundo a caracterização proposta por Lynch (1993), os caudillos, em sua origem, se definiram por uma tríade a partir do qual angariaram temor, respeito e poder, pautada por uma base econômica, uma implantação social e um projeto político.

No que tange à base econômica, os caudillos, cujo poder fora, primeiramente, de alcance estritamente local ou regional, eram, quase sempre, proprietários de terras, com intenso controle sobre a distribuição de bens e sobre a alocação do trabalho e das condições de subsistência em suas propriedades.

O poder dos caudilhos, todavia, não se expressava apenas sob o âmbito econômico. $\mathrm{O}$ uso da força e o exercício da liderança manu militari como expedientes de sua implantação social eram um signo comum àqueles chefes regionais. $\mathrm{O}$ ânimo guerreiro, conquistador, a reunião de homens para promoção de conquistas territoriais e para a acumulação de bens eram uma característica marcante do caudilhismo. Quanto à necessária relação entre o uso da força e a constituição do poder e da legitimidade dos caudilhos, é pertinente a transcrição do seguinte excerto da obra de Lynch (1993):

Un caudillo bien podía partir al galope desde su propria hacienda a la cabeza de un grupo de hombres armados y sus seguidores le estarían obligados por una serie de lazos personales determinados por relaciones de sumisión. Entre todos estos individuos cabe establecer un denominador común: se trata del deseo de obtener poder y riqueza mediante el uso de las armas. (LYNCH, 1993, p. 18-19.)

O fato de possuírem terras e de atuarem por meio da força não é suficiente, ainda, para a completa definição de um caudillo. Outro aspecto decisivo em seu mecanismo de poder eram os vínculos de patronagem que estabeleciam com os seus subordinados. Em tais relações, havia um desigual intercâmbio de vantagens, nos termos do qual o caudillo ofertava alguma proteção, meios de subsistência e, em contrapartida, aumentava seu contingente de guerreiros, sua influência política e sua força econômica. 
Tais vínculos de patronagem tendiam a repor liames horizontais entre os indivíduos, de tal arte que as identidades de classe sucumbiam à lógica vertical estabelecida entre o patrão personalista e aqueles que estavam sob sua égide. Essa estruturação social encerrava certa complexidade, de modo que um indivíduo poderia se comportar, em termos de exercício de influência e celebração de trocas desiguais, como patrão em relação à determinada coletividade e, a um só tempo, como cliente diante de outro líder que lhe fosse superior. Em que pese não contarem com qualquer grau de formalização ou positividade, as relações patrão-cliente eram rígidas e indissolúveis, além de, não raramente, imbricarem-se em vínculos familiares de compadrio, por meio das quais se afirmavam ainda mais intensamente. O projeto político do caudillo, portanto, concernia na crescente reunião de clientes sob seu pálio, de modo a ampliar seu poder territorial e materialmente.

Um poder central forte e consolidado não permitia o florescimento das relações informais e do exercício da violência típico dos caudillos. Assim, para Lynch (1993), a queda dos Bourbons em 1808 cedeu terreno a um vazio político-institucional no contexto do qual as lideranças informais, a princípio de alcance apenas regional, encontraram terreno para florescer. Sustenta o autor que a era do absolutismo fora politicamente substituída pelos tempos de caudilhismo. Nesse sentido, importa constatar a intensa correlação entre o fenômeno político em comento e as lutas por independência das colônias espanholas na América.

No contexto das Guerras de Independência, o caudilhismo encontrou condições favoráveis para que o poder dos líderes, então estritamente regional, almejasse um alcance nacional. O fato é que, ao mesmo tempo em que eram concebidos como guerreiros e desordeiros, avessos à unidade política e aos auspícios liberais que influenciavam as lutas independentistas, os caudillos eram fundamentais na manutenção da ordem social em suas áreas de domínio e, ademais, cumpriam importante papel na organização de extratos sociais indispensáveis para a independência, mas aos quais o poder central não conseguia chegar, como se dava com os gaúchos na Argentina e os pardos na Venezuela.

O papel dos caudillos nas lutas pela emancipação política das nações hispano-americanas ensejou o deslocamento do respectivo poder de um âmbito local para um alcance nacional, a partir do qual assumiria as características que lhe permitiram se definir como primeira manifestação da legitimação personalista do domínio político, já em grau de rivalização ou tensão em face dos projetos liberais e constitucionalistas. É pertinente, assim, constatar-se que o caudilhismo e o constitucionalismo são dois produtos dos processos de independência ocorrentes na América Latina do século XIX.

Na dialética - mas não contraditória - constituição de líderes que arregimentavam um séquito segundo vínculos de patronagem e ameaçavam a ordem e coesão social por meio de práticas associadas à desordem e agitação, mas que, igualmente, garantiam a ordem e estabilidade ao unificarem politicamente segmentos sociais onde os independentistas liberais não conseguiam penetrar, forjou-se o poder nacional dos caudillos. Tratava-se de uma composição de forças mantida pela constante ameaça à integridade estatal, conjugada por sua manutenção, não raramente em grau de composição e harmonização com as oligarquias, sob o crivo de um indivíduo como fator, a um só tempo, de estabilização e de potencial desestruturação das ainda incipientes ordens político-sociais pós-coloniais. 
Estrategicamente situados entre as camadas populares que controlam com rigor e sob lógica de violenta coerção, por um lado e, de outro lado, as oligarquias que dependem de ordem e estabilidade no contexto pós-independência, foi inevitável que os caudillos aspirassem a exercer o poder nacional conforme ditaduras orientadas segundo lógica personalista. Surge, assim, a última característica do personalismo caudilhista, concernente à reticência em abandonar o controle do Estado, de modo a se manter perpétua e plenamente no poder.

Em ácida crítica ao que entende como personalismo, caráter não civilizado, uso desmedido da força, cooptação pelo medo, controle da opinião pública e desprezo pelas instituições verificados no governo do caudillo Rosas, na Argentina, Sarmiento assim sumariza o alcance do poder exigido e, afinal, obtido por aquela liderança personalista, após a morte de Facundo, em texto que, inobstante referido a um caudillo em particular, se comunica ao anseio por poder total e à aversão às instituições que tais figuras usualmente ostentaram:

Porque Rosas no se há contentado, esta vez, con exigir la dictadura, las facultades extraordinarias, etc. No; lo que pide es lo que la frase expresa: tradiciones, costumbres, formas, garantías, leyes, culto, ideas, conciencia, vidas, haciendas, preocupaciones; sumad todo lo que tiene poder sobre la sociedad, y lo que resulte, será la suma del Poder público pedida. (SARMIENTO, [s. d.], p. 204.)

A partir das caracterizações aqui expostas, conclui-se que a primeira manifestação de liderança personalista na América Hispânica encerrou, em que pese suas variantes regionais, as seguintes características: a) gênese histórica do poder no controle de regiões, frequentemente associado à propriedade (formalizada ou não) fundiária; b) estabelecimento de relações de patronagem entre líderes e liderados, as quais, posteriormente, se projetaram nos governos nacionais exercidos pelos caudilhos; c) concomitante ameaça à ordem e garantia de sua manutenção, como mecanismo orientado a indicar o caráter indispensável da liderança personalista para a estabilidade social; d) expansionismo quanto ao território e aos grupos sobre os quais o poder era exercido, obtido, comumente, por conquistas e investidas de ordem militar; e) pouco ou nenhum apego às instituições formais, ou seja, à legitimação constitucional do Estado ou do poder; e) capacidade de liderança e de coordenação sobre setores sociais nos quais as demais estruturas de poder não conseguiam chegar, como os gauchos, na Argentina, ou os pardos, na Venezuela ; f) resistência à alternância de poder ou à renúncia do líder quanto às respectivas prerrogativas, ensejando tendências ao surgimento de regimes ditatoriais ou mesmo autocráticos; e g) identificação do Estado e de suas instituições com a pessoa do caudilho governante.

É possível concluir, a partir do que se apresentou, que o personalismo caudilhista seria o anverso da ideia liberal-constitucionalista de Estado que também influenciou fortemente as nações hispano-americanas egressas dos processos de independência. Todavia, mais do que uma simples luta entre esses dois tipos puros, a história da região presenciou manifestações de governo híbridas, em que convivam personalismo e constitucionalismo sob um mesmo contexto. Uma primeira expressão desse imbricamento se identifica nas ditaduras exercidas pelo libertador Simon Bolívar, conforme se pormenoriza na seção adiante. 


\section{ENTRE AS LIBERDADES CONSTITUCIONAIS E O CAUDILHISMO: O PERSONALISMO mitigado de Simon Bolívar}

Simon Bolívar é, indubitavelmente, uma dentre as poucas figuras históricas cuja atuação individual cumpriu relevantíssimo papel nos destinos de nações e no significado de toda uma época. Entre suas formulações constitucionais, sua liderança nas lutas independentistas e sua atuação como governante de distintas nações, Bolívar deixou importante legado institucional e simbólico na história da América Hispânica, cuidando-se de um raro exemplo de pensador e líder político que encontrou reconhecimento e notoriedade tanto em vida como postumamente, estabelecendo controvérsias e representando clivagens ao longo de quase duzentos anos na história política do subcontinente.

Nascido em Caracas no ano em que a Inglaterra reconheceu a independência dos Estados Unidos, 1783, Bolívar era órfão aos nove anos de idade, contando, primeiramente, com os cuidados do avô materno como tutor e, em seguida, de um tio. Este reserva ao futuro libertador uma dedicada educação, contando com os melhores preceptores caraquenhos e, em seguida, com uma continuidade dos estudos na Espanha, para onde Bolívar se desloca passando pelo México e por Havana. Segundo testemunha em carta enviada a Francisco de Paula Santander, Bolívar teve a oportunidade de conhecer, nessa ocasião, a obra de pensadores como Locke, Condillac, Buffon, D’Alembert, Helvetius, Montesquieu, Voltaire e Rousseau. Este último, como adiante se verá, o influenciaria significativamente em suas concepções sociopolíticas.

Bolívar regressa à Venezuela em 1809 e, no ano seguinte, é acusado de tomar parte em uma conspiração em favor de uma junta, em nome de Fernando VII, que substituiria o Capitão General D. Vicente no Cabido de Caracas, à época em que Espanha se encontrava sob a intervenção napoleônica. Em nome da referida junta, aliás, Bolívar chega a integrar uma missão à Inglaterra, onde tem contato com as respectivas instituições, as quais muito o impressionam favoravelmente.

De volta à Venezuela, Bolívar ingressa em um grupo que viria a se tornar a favor da independência perante a Espanha, denominado Sociedade Patriótica. A partir daí, o libertador levaria uma intensa e turbulenta vida, em meio a inúmeras lutas por independência em localidades como, dentre outras, a atual Colômbia, Peru e Bolívia, a nação que deu seu nome ao líder e pensador político. Ao mesmo tempo em que se engajou em lutas, Bolívar exerceu, por ao menos vinte anos, funções de governante em países como Venezuela, atual Colômbia e Peru. Fora, ainda, um autêntico formulador constitucional, conforme atestam seus projetos apresentados em Angostura no ano de 1819 e na Bolívia em 1825. O grande projeto de Bolívar, concernente à instituição de uma grande confederação de países hispano-americanos, soçobrou e, já no fim de sua vida, o libertador assistiu a uma tendência às secessões entre as antigas colônias, conduzidas, dentre outros, por Paéz, um caudillo que outrora fora seu aliado de confiança na emancipação venezuelana.

Bolívar morre em 1830 e, em que pese ter conjugado uma intensa atividade política, teórica e militar, se encontra desacreditado ao final da vida, conforme confessa em missiva enviada para Juan José Flores, em cujos termos diz ter governado por vinte anos e encontrado 
poucos resultados certos, chegando a afirmar que "fazer uma revolução é lavrar no mar" (BOLÍVAR, 1977, p. 191).

Não chega a surpreender que as ideias de alguém que acumulava incumbências de formulação teórica concomitantemente à condução de batalhas, medidas governativas e toda sorte de turbulências possam encontrar tensões constitutivas ou eventuais ambiguidades. Soma-se a isso o fato de Bolívar, intensamente inspirado pelo pensamento democrático-constitucional europeu, obstinar-se por se reportar às peculiaridades de Hispano-América e, assim, tem-se um pensador irredutível à clivagem democrata $\mathrm{x}$ ditador, ou à pura tipificação entre constitucionalismo e personalismo.

Por um lado, identifica-se em Bolívar, de modo a diferenciá-lo dos caudillos abordados na seção anterior, um claro apreço pelo constitucionalismo, pela legitimidade institucional do domínio político e pela democracia. A simples constatação de que fora o prócer de dois textos constitucionais (Angostura-1819 e Bolívia-1825) já é um importante indicador dessa constatação.

Em discurso proferido em Angostura no ano de 1819, Bolívar é enfático em seu apreço à soberania popular e, diferentemente do que se dá no marco do personalismo, defende a alternância de poder (na ocasião, aliás, ele renuncia ao governo da Venezuela, em que pese tal decisão não perdurar) e expressa que "a manutenção da autoridade pelo mesmo indivíduo tem habitualmente conduzido ao termo vários governos democráticos" (BOLÍVAR, 1977, p. 113). Vê-se aqui um Bolívar tipicamente constitucionalista, quiçá liberal, a sustentar mandatos limitados no tempo e a afirmar, em seu próprio desfavor, que os cidadãos devem "recear com dobradas razões que um único magistrado, que os governou durante muito, queira governá-los perpetuamente" (BOLÍVAR, 1977, p. 113). Assim ditas, trata-se de palavras que jamais seriam expressadas por personalistas típicos, os caudillos, como Rosas e Paéz. No mesmo sentido, Bolívar é explícito em suas influências e expressa que a Constituição britânica "é a que parece destinada a operar o maior bem possível entre os povos que a adoptam” (BOLÍVAR, 1977, p. 119).

Mas o constitucionalismo de matriz europeia do pensador e líder político não vai além disso, de modo que inúmeras inflexões, ainda mais acentuadas em seu trabalho junto à Constituição da Bolívia de 1825, são efetivadas sobre a legitimação institucional do domínio político e em favor de traços manifestadamente personalistas. No próprio discurso de Angostura, logo após se revelar apologético em relação à Constituição britânica, Bolívar ressalva que está "muito longe de propor uma imitação servil" (BOLÍVAR, 1977, p. 119). É a partir dessa premissa, ou seja, nos termos do próprio autor, de quem formula e luta por instituições para "americanos por nascimento e europeus por direitos" (BOLÍVAR, 1977, p. 115), que se apresentam ações e normas de natureza claramente personalista, tal como a seguir se expõe.

A relação entre Bolívar e o personalismo é marcada por uma progressiva adesão à política ancorada no líder, para além das instituições, o que se depreende de suas distintas concepções esposadas em Angostura e, posteriormente, na Bolívia. Em qualquer caso, é notável a preocupação do autor, um republicano no forte sentido rousseauniano do termo, com o que entende como a necessidade de que um bom governo se situe em posição equidistante 
da tirania e da anarquia. Com vistas a evitar o triunfo desta última, Bolívar dá ensejo a práticas e propostas personalistas.

Ainda em Angostura, o autor recorre a exemplos históricos, como Atenas, para propor que a legitimidade calcada em leis não é suficiente para garantir a longevidade e estabilidade do Estado. De modo condizente com a ideia de legitimação do poder político segundo o carisma do governante, Bolívar afirma que "os códigos, os sistemas, os estatutos, por mais sábios que sejam, são obras mortas que pouca influência têm sobre as sociedades. Os homens virtuosos, os homens patriotas, os homens ilustrados são quem verdadeiramente constitui as Repúblicas" (BOLÍVAR, 1977, p. 127). Sob tais bases, o libertador oscila entre uma contenção dos poderes presidenciais, ao afirmar que o chefe do Poder Executivo, no exercício de suas atribuições, será sempre objeto de controle por seus ministros e suscetível de acusação perante o Senado, mas a sustentar, igualmente, que "nada é tão perigoso em relação ao Povo como a fraqueza do Executivo" (BOLÍlVAR, 1977, p. 135).

O personalismo não se expressa, no texto apresentado em Angostura, apenas no que se refere ao Poder Executivo, mas, igualmente, na proposição de um bicameralismo em que um Senado vitalício e hereditário, composto por homens virtuosos, educados para o exercício da função pública, mas, igualmente, pelos carismáticos (e, não raramente, caudillos) lutadores da independência, a quem Bolívar qualifica como seres "prudentes e esforçados que, superando todos os obstáculos, fundaram a República” (BOLÍVAR, 1977, p. 133). Os senadores vitalícios, entendidos pelo autor como a base do governo, cumpririam o papel de refrearem os ardores e demandas populares que poderiam conduzir à anarquia. Em suma, heróis da independência, por seus atributos individuais, cumpririam o papel de contrapeso à soberania popular, algo que, no constitucionalismo majoritariamente assumido em nossos dias, reservar-se-ia aos direitos fundamentais, assim garantidos pela jurisdição constitucional.

Em suma, o Bolívar de Angostura, ao pretender encontrar um ponto médio entre a anarquia e a tirania, acaba por dar vazão a uma síntese entre legitimidade constitucional e personalista do poder político, atribuindo, assim, significativa relevância aos dons e atributos individuais dos governantes, para além dos controles formais ou dos mecanismos de exercício da soberania popular ${ }^{(4)}$.

No projeto constitucional que apresenta à Bolívia (nação que o homenageara em vida por meio da escolha do próprio nome), seis anos após o Discurso de Angostura, Simon Bolívar já se revela mais próximo do personalismo, exacerbando aspectos de sustentação do poder em lideranças individuais que se encontravam apenas latentes ou incipientes em 1819. Ainda assim, o libertador distante está de se enquadrar em uma lógica caudilhista, ao tempo em que ainda reserva ímpar relevância às instituições e aos sistemas que hoje chamamos de accountability horizontal. Nesse sentido, apenas como exemplo, nota-se a formulação de um quarto poder para a República, denominado Eleitoral, a se compor

(4) Ressalva-se, entretanto, que tal personalismo é sempre mitigado e está em tensão interna com a complexa divisão de poderes formulada pelo Libertador (que institui uma autêntica figura denominada Poder Moral) e com constatações claramente avessas ao personalismo, como a ideia de que, no Poder Executivo que defende, o arranjo institucional assegura que " $[\mathrm{P}\rceil$ ode acontecer que não seja o presidente um homem de grandes talentos, ou de grandes virtudes, e não obstante a ausência destas qualidades essenciais, desempenhar os seus deveres de forma satisfatória” (BOLÍVAR, 1977, p. 134). 
segundo uma proporção de um representante para cada dez cidadãos e revestido da incumbência de proteger os cidadãos contra eventuais abusos advindos do Poder Executivo.

Estabelecidas as ressalvas acima, ainda resta um núcleo personalista com forte expressão no texto apresentado em 1825. Primeiramente, nota-se a opção por um mandato vitalício para o Presidente, a ser sucedido por um Vice-presidente que seria empossado por sua escolha. Ou seja, não haveria qualquer alternância quanto ao magistrado maior da República. Bolívar justifica tal opção ao sustentar que o Presidente teria atribuições limitadas, de tal arte que suas funções seriam, prevalecentemente, simbólicas. Não é que se conclui, contudo, das competências que lhe são atribuídas: "nomear os funcionários da Fazenda, a paz e guerra e mandar no Exército” (BOLÍVAR, 1977, p. 158).

Ora, inúmeros teóricos do Estado moderno tendem a oscilar na caracterização do domínio político como monopólio da violência legítima (WEBER, 1982), ou como um aparato fazendário destinado ao controle da produção em favor de determinado modo de geração e distribuição de riquezas (cf. SCHUMPETER, 1991; O'CONNOR, 1977). Assim, a entrega de competências militares e fazendárias a uma só autoridade, vitalícia, com poderes para indicar o próprio sucessor, atesta um claro signo personalista na Constituição apresentada em 1825, o qual, ainda, se evidencia na caracterização desse líder como "o Sol que, firme no seu centro, dá vida ao Universo" (BOLÍVAR, 1977, p. 155). É igualmente importante notar como Bolívar, que exerceu em diferentes circunstâncias poderes ditatoriais, pretende que a Constituição da Bolívia sirva de modelo para um arranjo federativo que congregue as nações de Hispano-América e, em ato falho que revela seu claro apego pelo papel de líder respaldado em carisma que exercia, chega a designar por diversas ocasiões o texto de 1825, em carta enviada a Sucre no ano de 1826, como "minha constituição" (cf. BOLÍVAR, 1977, p. 173-178).

O que se infere do pensamento e da atuação política de Bolívar é um claro distanciamento em relação à liderança autocrática e patronal dos caudillos (com quem, por razões aparentemente de ordem estritamente tática, teve de se aliar no contexto de lutas por emancipação política das colônias de Hispano-américa), de maneira a se evidenciar um pensamento constitucionalista, um intenso apreço à soberania popular e, por conseguinte, uma aversão às tiranias. Resta, contudo, na vida e obra do libertador, um tipo específico de personalismo, mitigado, que se encontra presente nos seguintes elementos: a) defesa de um Poder Executivo vitalício, sucedido por pessoa escolhida pelo Presidente; b) ênfase no brilho e virtude dos governantes como variáveis mais relevantes do que as leis e instituições para a consecução da harmonia e da estabilidade política; c) exercício, por mais de uma ocasião, de funções governativas revestidas de atribuições ditatoriais; e d) oferta de vagas em Senado vitalício e hereditário para lideranças individuais, com fulcro em seus serviços historicamente prestados no contexto das guerras de independência.

A conciliação entre o discurso da liderança pessoal e o da soberania popular, presente em Bolívar, encontra uma segunda manifestação na América Latina. Já no limiar da urbanização, industrialização e modernização, teve lugar um fenômeno político em que tais figuras se pretendem complementares. Trata-se do populismo, objeto de apreciação na seção subsequente. 


\section{O POPUliSMO: POLISSÊMICA CATEGORIA ASSOCIADA AO PERSONALISMO MODERNO}

A primeira cautela metodológica que um discurso sobre o populismo deve adotar se refere à constatação da intensa polissemia a incidir sobre a categoria, de modo a, invariavelmente, obstar um mínimo de rigor ou clareza em seu emprego. Assim, preliminarmente à estrita abordagem dessa variação da legitimação personalista do poder político na América Hispânica, cumpre uma breve revisão dos elementos de que tal ideia se compõe em distintas manifestações da literatura, o que far-se-á com amparo em artigo de Guy Hermet (2003).

Primeiramente, em diálogo com a definição proposta por autores como Edward Shils e Lloyd Fallers, Hermet (2003) dialoga com uma noção de populismo que remete à própria etimologia do termo, ou seja, à primazia do povo e da soberania popular, para além de clivagens como classe. O apreço do governante pelo povo - assim concebido segundo um sentido unitário, claramente republicano - e suas demandas seria o atributo mais importante do fenômeno político em comento. A se anuir com tal definição, a associação entre personalismo e populismo aqui proposta não seria tão direta como se presume. Ocorre que, como pondera Hermet (2003), a redução do populismo à exaltação da soberania popular não é analiticamente suficiente para se discriminar a noção. Como se sabe, a democracia (em especial a chamada democracia radical) e, a seu modo, até mesmo o fascismo, operam sobre as bases de que a centralidade do poder e de sua legitimidade reside no povo e em suas demandas. Tão ampla definição, portanto, se revela insuficiente para a especificação do termo, de modo que outros elementos devem ser cogitados (cf. HERMET, 2003).

Identificados os problemas de uma definição formal da categoria populismo, estribada em um apego à cambiante vontade popular, Hermet vai em busca de uma apreciação mais substantiva sobre o tema, de modo a aferir se o populismo seria uma ideologia, ou seja, uma pauta concreta de valores, ideias, moralidade política e diretivas quanto ao governo. Também quanto a este critério, percebe o autor, a ideia não pode ser precisada. O fato é que não há liame ideológico ou moral que permita a percepção de regularidades entre as mais distintas manifestações governativas albergadas sob o epíteto do populismo. Outras variáveis, assim, ainda precisam ser levadas em conta (cf. HERMET, 2003).

Já se aproximando do objeto deste trabalho, Hermet avalia se o apego a uma liderança carismática seria, por si só, uma particularidade do populismo. Se é verdade que o autor reconhece tal atributo em todos os governos identificados como populistas (o que parece ratificar a premissa do presente estudo), igualmente correta é a constatação de que a legitimidade segundo um apelo à liderança individual do governante não é um traço distintivo entre o populismo e outras manifestações de justificação do domínio político com fulcro no carisma, bastando, para se comprovar tal assertiva, uma referência aos tipos de personalismo abordados nas seções anteriores.

Diante dos limites encontrados nos critérios acima expostos, Hermet persegue outro elemento a particularizar o populismo e o encontra, ancorado na obra de H. Jaguaribe, na relação entre o governo e o tempo da política. Para o autor, os governos populistas se orientam pela oferta de solução rápidas e, recorrentemente, anômalas em relação ao ritmo esperado de uma administração pública, de modo a se aquietar demandas populares. Este 
traço, somado ao personalismo e ao apego à soberania popular (que não seriam exclusivos do fenômeno) definiria o populismo. Confira-se, a propósito, os termos do próprio Hermet:

No cabe duda de que esta promesa de realización en un lapso muy breve contituye el elemento de definición esencial del populismo, teniendo claro que su immediatez procede también de su lógica de mediación directa, sin pantallas, sin complicaciones institucionales y sin plazos. La única definición discriminante del populismo reside en estas dos dimensiones, parientes de la promesa immediatamente realizable y de la no-mediación, que garantiza la respuesta instantánea. (HERMET, 2003, p. 10.)

Independentemente de uma aceitação integral da análise proferida por Hermet, depreendem-se do seu estudo alguns atributos importantes para fins de classificação do populismo em geral e comunicáveis ao específico caso hispano-americano: a) ênfase na soberania popular e uma concepção republicana, unitária, de povo; b) exercício do poder por um governante carismático e dotado de intenso respaldo pessoal junto aos cidadãos; c) ausência ou pouca influência de canais de mediação entre governante e governados; e d) modo de atuação que se concentra sobre o imediatismo, ou seja, sobre a rápida resposta e demonstração de resultados em relação às demandas apresentadas ao governo. Por sofisticada que a caracterização acima seja, alguns elementos adicionais devem ser incorporados ao conceito de populismo, ao menos na variante aqui em questão, qual seja, a da América Latina. A seguir, portanto, apresentam-se algumas considerações tecidas por Ernesto Laclau (2006) sobre o tema.

Para Laclau (2006), o populismo se afigura como uma resposta ao contexto observado a partir da década de 30 do século XX, no qual as consolidadas estruturas oligárquicas de poder já não conseguiam dar respostas às demandas populares de uma classe média em formação e de uma população que se deslocava do campo para os centros urbanos. Em um cenário nos quais multiplicavam-se demandas sociais, de naturezas distintas, sempre opostas contra as oligarquias (e, por derivação simbólica, contra o liberalismo que representavam), têm lugar "cadeias equivalenciais" entre distintas reivindicações, por meio das quais sua multiplicidade pode fazer sentido e encontrar canais institucionais de expressão (cf. LACLAU, 2006).

Tais "cadeiais equivalenciais", no caso do populismo latino-americano, não são constituídas por demandas comuns que conformam reivindicações positivas ou conceituais, de modo que se irmanam em unidades negativas ou nominais. Nominais, aqui, entendidas no exato sentido de que desaguam em um nome próprio, ou seja, "un nombre (singular)..., lo que explica el rol del líder: en su nombre cristaliza la unidad del movimento” (LACLAU, 2006).

Laclau (2006), a partir da constatação de que o populismo surge de demandas concretas da população e tem na liderança pessoal um ponto de chegada, antes de sua gênese, não compartilha da apreciação crítica que usualmente se atribui ao fenômeno:

Se vocifera contra esa centralidad en el caso del populismo, pero en outros casos ella no es el blanco de los mismos denuestos. ¿Podemos imaginar la transición a la Quinta República en Francia sin la centralidad política de la figura de De Gaulle? No que el líder sea origen del movimiento, sino que, si esse punto de aglutinación, el movimento 
no podría forjar su unidad, se dispersaria entre los elementos que lo componen. Este es tanto más el caso cuando la fragmentación social es mayor, el proceso de institucionalización más avanzado. (LACLAU, 2006.)

Em conclusão, somam-se às características já enunciadas os seguintes elementos a definirem o conceito de populismo na América Latina: a) consequência de limitações institucionais para processarem as demandas de uma classe média urbana, em meio a crises e processos de industrialização ainda incipientes; b) fator de coesão de demandas que, contudo, se define nominalmente, antes de conceitualmente, ao redor do líder; e c) como fator de coesão apenas nominal, não se revela como signo de auto-organização ou de tomada de consciência por parte das massas.

Uma vez identificadas as principais características das variantes caudilhista, bolivariana e populista de personalismo na América Hispânica, cumpre indagar se há algum liame histórico ou lógico entre tais fenômenos e se, eventualmente, se projetam na realidade contemporânea. É ao que se propõe a seção conclusiva, a seguir.

\section{Conclusões}

Caetano Veloso, um popular músico brasileiro, se pergunta em uma música "se nunca faremos senão confirmar, a incompetência da América Católica, que sempre precisará de ridículos tiranos". A história do subcontinente, contudo, talvez não seja tão cruel como os versos do cantor parecem sugerir.

O fato é que as três variações de personalismo político em Hispânico-América, tal como aqui perquiridas, não podem ser entendidas como uma continuidade de processos tirânicos e ilegítimos de dominação do povo. Primeiramente, o que se notou é que cada variante de personalismo se explica em razão das especificidades inatas ao contexto em que ocorrem. Nesse sentido, não é possível aludir-se ao caudilhismo sem se considerar a economia rural do seu tempo, as alianças que foram necessárias nas lutas por independência e as estruturas regionais de poder. Igualmente, não é dado replicar-se automaticamente o ambíguo personalismo de Simon Bolívar, haja vista se tratar de resposta circunscrita ao tão peculiar contexto de emancipação das colônias espanholas na América. Do mesmo modo, o populismo só pode ser explicado como fenômeno colateral à dificuldade das instituições, concebidas para realidades prevalecentemente agrárias, processarem a multiplicidade de demandas oriundas do campo mas, fundamentalmente, de uma população que se tornava crescentemente urbana.

Com efeito, os elementos aqui levantados indicam que não há vínculos mecânicos a permitirem a associação entre os personalismos ocorrentes em Hispano-América, assim como não se pode atribuir a uma "cultura política" ou a qualquer sina irremediável a ocorrência de tal justificação carismática do domínio político.

Há, de qualquer modo, alguns aspectos a indicarem uma associação, nunca causal ou mecânica, mas apenas analítica, entre as distintas manifestações do personalismo na política da América Hispânica. O que ressai de comum nas variantes caudillista, bolivariana e populista 
do personalismo, a partir das características que foram aqui expostas, é uma afirmação da identidade subcontinental, em momentos de crise, que se forja na tematização da alteridade, ou seja, na negação do modelo político triunfante nos países centrais.

A tensão entre constitucionalismo e personalismo não se equaciona, assim, como um simples caso da clivagem democracia x ditadura, ou como um caminho em espiral que contaria com avanços na racionalização do Estado (legalidade) e supostos retrocessos concernentes ao estabelecimento de governos legitimados segundo o carisma. A liderança carismática é, recorrentemente, a alternativa encontrada para que a região se afirme e construa sua identidade política e institucional, ainda que sob a lógica da negação. Este é, possivelmente, um fator explicativo da recorrente associação entre anticolonialismo e anti-imperialismo com os governos personalistas.

Em que pese as constatações acima, nota-se que, em um mundo cada vez mais integrado cultural, econômica e politicamente, sob o crivo da desigualdade e iniquidade, é relevante proceder-se a uma avaliação crítica das consequências do personalismo na conformação política do subcontinente, sem que tal leitura implique necessariamente um etnocentrismo metodológico. Não seria metodologicamente produtivo entender-se o personalismo como uma manifestação peculiar, local, apartada do contexto mundial e que, como tal, deve ser aceita e compreendida. É necessário perscrutar-se as consequências desse fenômeno, com certo cunho normativo, para além de apenas descrevê-lo.

A longo prazo, uma importante consequência do personalismo é o sacrifício da autonomia pública, ou seja, dos canais sociais e políticos que permitem aos cidadãos vocalizarem demandas positivas, controlarem o exercício do poder e, sobretudo, constituírem identidades políticas que possam ir além da afirmação de uma alteridade. O mesmo líder carismático que, em determinado momento, vocaliza demandas, estabiliza crises e enfrenta a dominação externa, se constitui, ato contínuo, como fator de represamento da auto-organização e expressão política dos cidadãos, ou seja, da manifestação de sua autonomia pública.

Sociedades complexas, urbanas, estratificadas e organizadas segundo interesses redistributivos e recognitivos díspares e rivais não comportam, sob pena de negarem seguimento a demandas e à influência política de extensas parcelas das respectivas populações, reduzirem-se politicamente aos termos de um líder carismático. Não há outro caminho: por progressistas que sejam os objetivos da conformação personalista do poder, associada à negação da dominação exercida pelos países centrais, essa forma de legitimação e condução do Estado implica, necessariamente, haja vista sua incapacidade de processar as complexas demandas de sociedades industriais, o sufocamento da sociedade civil e a contenção dos grupos auto-organizados.

Um exemplo do argumento acima exposto se consubstancia no governo do Tenente-coronel Hugo Chávez, Presidente da Venezuela contemporânea. Sob auspícios de afirmação da autonomia subcontinental, em claro enfrentamento perante os governos centrais, respaldado por amplas massas populares e reverenciado como exemplo e alternativa para ativistas e intelectuais de esquerda em todo o mundo, o forte personalismo com que conduz o país implica, inevitavelmente, uma contenção das organizações autônomas da sociedade civil venezuelana, uma burocratização das demandas sociais e dos processos públicos, além 
de uma restrição das liberdades civis e organizativas incompatível com a ideia de autonomia pública.

Chávez, no afã de estabilizar o governo em seu entorno, controla os sindicatos do país, negando-lhes autonomia e submetendo o respectivo processo eleitoral às regras $\mathrm{e}$ procedimentos da burocracia estatal. No que se refere à comunicação social, reserva a si uma superexposição midiática, por meio de canais de radiodifusão estatal, centralizando, portanto, a esfera pública e política em seu nome, de modo a até mesmo revogar a concessão do serviço de radiodifusão de um canal que lhe fazia oposição. No que se refere ao âmbito partidário, o governante se esforça para agrupar toda a esquerda e o centro político sob uma legenda única, o PSUV, de modo a dar vida à divisa tão criticada por Sarmiento em Rosas, a dizer "el que no está conmigo es mi enemigo" (SARMIENTO, [s. d.], p. 206).

Tem-se, portanto, uma manifestação contemporânea de personalismo, em muito assemelhada ao populismo, ainda que se reivindicando da herança de Simon Bolívar. O que, nesse sentido, cabe indagar, é se o subcontinente pretende continuar a se afirmar na alteridade, sacrificando a autonomia pública e a auto-organização da sociedade no altar de governos carismáticos que prometem, a partir do líder, uma emancipação social sempre postergada, não em decorrência de ânimos tirânicos ou vícios subjetivos do governante personalista, mas da limitação estrutural para que uma pessoa sintetize as demandas de um complexo povo, cumprindo um papel de estuário da dinâmica política e social.

\section{REFERÊNCIAS BIBLIOGRÁFICAS}

BOLÍVAR, Simon. Escritos políticos. Trad. Maria Clarinda Braz e Armando Silva Carvalho. Lisboa: Martins Fontes, 1977.

HABERMAS, Jürgen. O ocidente dividido. Trad. Luciana Villas Bôas. Rio de Janeiro: Tempo Brasileiro, 2006.

HERMET, Guy. El populismo como concepto. In: Revista de Ciencia Política, v. XXIII, n. 1, p. 5-18, 2003.

LACLAU, Ernesto. Consideraciones sobre el populismo latinoamericano. In: Cuadernos del Cendes, v. 23, n. 62, Caracas, maio 2006.

LYNCH, John. Caudillos en Hispano-América: 1800-1850. Trad. Martín Rasskin Gutman. Madrid: Mapfre, 1993.

O'CONNOR, James. USA: A crise do estado capitalista. Trad. João Maia. São Paulo: Paz e Terra, 1977.

SARMIENTO, Domingo Faustino. Facundo. Disponível em: <http://www.bibliotecayacucho.gob.ve> Acesso em: 25. abr. 2011.

SCHUMPETER, Joseph A. The crisis of the tax state. In: SWEDBERG, Richard (Org.). Joseph A. Schumpeter: the economics and sociology of capitalism. Princeton: Princeton University Press, 1991.

WEBER, Max. A política como vocação. In: Ensaios sociológicos. Trad. Waltensir Dutra. Rio de Janeiro: LTC, 1982. 